\section{Alcides Carvalho and the selection of Catuaí cultivar: interpreting the past and drawing lessons for the future}

\section{Oliveiro Guerreiro Filho ${ }^{1}$, Magno Antônio Patto Ramalho ${ }^{2}$ and Vinícius Teixeira Andrade ${ }^{1^{*}}$}

\begin{abstract}
The coffee cultivar Catuai is among the most successful cultivars in Brazilian agriculture; it has been on the market for more than 40 years. It was obtained by Dr. Alcides Carvalho, a researcher of the Instituto Agronômico de Campinas (IAC), from the cross between 'Caturra' and 'Mundo Novo' carried out in 1949 for the purpose of joining plant vigor with small plant size. Our aim was to report the activities that culminated in the recommendation of 16 lines of 'Catuai', consisting of eight lines with red fruit and eight with yellow fruit, analyzing the data of several experiments. The decision regarding what to recommend was made in the $F_{1: 2}$ generation, based on two harvests. It became clear that Dr. Alcides should be taken as an example by all breeders, above all in his persistence, scientific rigor, and belief that farmers can be an important ally of breeders.
\end{abstract}

Keywords: Plant breeding, Coffea arabica L., coffee genetic improvement, quantitative genetics, successful breeder.

\section{INTRODUCTION}

Coffee was and will continue to be one of the main export products of Brazil. In addition, Brazilian coffee production meets the demand for internal consumption, and Brazil is the second largest consumer of coffee worldwide. Brazilian coffee growing is of enormous socio-economic importance and is the basis of revenue of various municipalities in the main producing regions.

Over the years, the yield of Brazilian coffee fields has increased considerably. Among the main causes are improvement in crop management and, above all, the use of new cultivars. The cultivar Mundo Novo released in 1952 and still grown now, is $240 \%$ higher yielding than the 'Nacional' or 'Típica' coffee in Brazil (Carvalho 1965).

Among the cultivars recommended, many of them, such as 'Mundo Novo', remain in the market for many years and continue to be used as parents of the new lines that are produced. In this aspect, the cultivar Catuaí, originating from the cross between 'Caturra' and 'Mundo Novo' (Carvalho and Mônaco 1972), stands out in yield and plant architecture and especially in the longevity of its use.

When speaking of the 'Catuaí' and several other coffee cultivars, the importance of studies performed by Dr. Alcides Carvalho, researcher of the IAC, who dedicated his brilliant professional life to coffee crop, is not to be
Crop Breeding and Applied Biotechnology 18: 460-466, 2018 Brazilian Society of Plant Breeding. Printed in Brazil http://dx.doi.org/10.1590/198470332018v18n4p69 
forgotten. Most importantly, as an example to new Brazilian breeders, it is important to periodically show the persistence, dedication, and scientific rigor characteristics of his studies. The IAC maintains all the records of the breeding program carried out that gave rise to the Catuaí cultivar, which includes the period from 1949 to 1972, considering selection and recommendation from performance in the $F_{3}$ generation. The aim of this study was to report the activities and, above all, interpret the set of results available in IAC for the purpose of maintaining the work of Dr. Alcides Carvalho alive in our memory, showing the effectiveness of the early selections of plants made in the $F_{1: 2}$ and $F_{2: 3}$ generations, his insight in identification of problems and in definition of scientific experimentation strategies.

\section{MATERIAL AND METHODS}

The experiments related to breeding of 'Catuaí' coffee were conducted by Dr. Alcides Carvalho mostly at the experimental stations of the IAC, São Paulo (SP) state, among other several locations.

The cultivars Caturra Amarelo, of short plant size and yellow fruit, and Mundo Novo, of tall plant size and red fruit, were used as female and male parents, respectively, in hybridization carried out in 1949 in Campinas, and $F_{1}$ seeds were obtained in 1950. $F_{1}$ coffee plants obtained from germination of 27 seeds were initially evaluated in a nursery, in 1950 and 1951, and 3 plants were selected and identified as H2077-1, H2077-2, and H2077-3 for planting in 1952 in Campinas. The $\mathrm{F}_{2}$ seeds obtained from self-pollination of the $3 \mathrm{~F}_{1}$ plants gave rise to $447 \mathrm{~F}_{1: 2}$ coffee plants (Table 1), evaluated in Campinas (395) and Mococa (52), and planting was carried out in 8 experiments - in 1956 (3), 1961 (3), and 1962 (2). Data on fruit yield of individual plants were obtained from various partial harvests of ripe fruit (Carvalho et al. 1952), and the number of harvests ranged from 8 to 14, depending on the experiment.

The $F_{2: 3}$ generation, composed of 1371 plants (Table 1), came from $9 F_{1: 2}$ plants and the number of descendants from each one of them was variable, from 24 to 409. The coffee plants of the $F_{2: 3}$ generation were planted in 17 experiments, with one plant per hill in 1960 (7), 1961 (5), 1962 (3), 1964 (1), and 1967 (1). The lines IAC 376-14 and IAC $379-19$ of the cultivar Mundo Novo were used individually or in combination as experimental controls. The number of harvests from each experiment ranged from 5 to 12 .

From the $1371 \mathrm{~F}_{2: 3}$ plants, 101 progenies were derived, now in the $F_{3: 4}$ generation, from a total of 3986 plants, evaluated in 24 experiments (Table 1) conducted from 1964 to 1970. The number of plant per plot and the number of plants per hill were variable. The identity and the number of progenies varied among the experiments, as well as the number of harvests, from 4 to 11.

The experimental data analyzed by Alcides Carvalho 45 years after release of the cultivars Catuai Vermelho and Catuaí Amarelo in 1972 were used in construction of a database and analyzed in each one of the generations, from $F_{1.2}$ to $F_{3: 4}$. The coffee 'Mundo Novo' was used as a control in combined analysis of the coffee plants.

Experimental data continued to be obtained even after recommendation of the cultivars for cultivation in 1972 . The information used in this study was compiled in the files of the program in IAC. The data were clustered for each one

Table 1. Number of experiments, of progenies, and of plants analyzed per generation, and locations of evaluation of experiments in selection of Catuaí cultivar

\begin{tabular}{|c|c|c|c|c|c|}
\hline Generation & Plants & Progenies & Experiments & Locations & Plants selected \\
\hline \multicolumn{6}{|c|}{ Total indicators } \\
\hline $\mathrm{F}_{1}$ & 27 & 1 & 1 & 1 & 3 \\
\hline $\mathrm{F}_{1: 2}$ & 447 & 3 & 8 & 2 & 9 \\
\hline $\mathrm{F}_{2: 3}$ & 1371 & 9 & 17 & 6 & 101 \\
\hline $\mathrm{F}_{3: 4}$ & 3986 & 101 & 24 & 9 & \\
\hline \multicolumn{6}{|c|}{ Indicators of the 'Catuaí' genealogy } \\
\hline $\mathrm{F}_{2: 3}$ & 172 & 1 & 3 & 3 & $52^{\text {H2077-2-5-** }}$ \\
\hline $\mathrm{F}_{3: 4}$ & 2405 & 52 & 18 & 9 & $16^{* *}$ \\
\hline
\end{tabular}

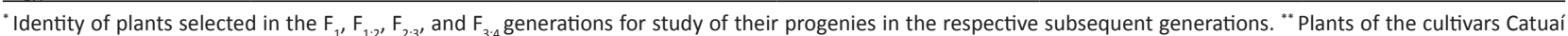
Vermelho and Catuaí Amarelo listed in the National Cultivar Registry of the Ministry of Agriculture (Ministério da Agricultura, Pecuária e Abastecimento). 
of the generations $\left(F_{1: 2}, F_{2: 3^{\prime}}\right.$ and $\left.F_{3: 4}\right)$. The term $F_{1: 2}$ was used because among the plants of the $F_{1}$ generation, there was segregation. In analyses of variance of the $z$ experiments conducted with the $F_{1: 2}$ generation, the following model was considered: $Y_{i j}=m+p_{i}+c_{j(i)}$, in which $Y_{i j}$ is yield in grams of ripe fruit per plant of plant $i$ in harvest $j ; m$ is the overall mean; $p_{i}$ is the plant $i(i=1,2 \ldots n)$, and $c_{j(i)}^{i j}$ is the effect of harvest $j$ within each plant $i(j=1,2 \ldots q)$. To compare the mean yield of the plants of the different experiments, the mean of the control common to all the experiments was used by the estimator: $\hat{Y}_{i z}=Y_{i z}-\left(T_{z}-T\right)$, in which $\hat{Y}_{i z}$ is the mean adjusted yield of plant $i$ in $q$ harvests in experiment $z, Y_{i z}$ is the mean yield of plant $i$ obtained in experiment $z ; T_{z}$ is the mean yield of the control in experiment $z ; T$ is the overall mean yield of the controls in all experiments. The analyses of variance of the $F_{2: 3}$ generation were carried out in a way analogous to that described for the $F_{1: 2}$ generation, as well as the adjustments of the mean values involving all the experiments. For analysis of variance of the $F_{3: 4}$ generation we used the split-plot-in-time-model (Steel et al. 1997).

To verify adaptation of the lines of the Catuai cultivar in the diverse coffee production regions, the experimental results of competition of progenies published from 1973 to 2017 in the annals of the Brazilian Coffee Research Conference (Congresso Brasileiro de Pesquisa Cafeeira) were reviewed. All the experiments that contained 'Catuaí' lines as a standard were considered in the analysis. A total of 116 summaries that included 9 Brazilian states in 22 counties were catalogued.

\section{RESULTS AND DISCUSSION}

The scientific article that marked the release of the Catuaí cultivar was published in 1972, 24 years after the hybridization that gave rise to it in 1949. Yet today, 'Catuaí' is the arabica coffee cultivar most planted in Brazil. The research work still has repercussions 45 years after official release of the principal lines, 8 of Catuaí Amarelo and 8 of Catuai Vermelho, showing the importance of the research done and the publication that reported it. In the title of the study, emphasis was directed to transfer of the caturra allele to 'Mundo Novo', which changes the length of the internodes of orthotropic and plagiotropic branches, reducing plant height and plant canopy diameter, respectively.

According to his reports, the aim of the cross 'Caturra' and 'Mundo Novo' would be to generate a new cultivar joining the hardiness, vegetative vigor, and yield potential of 'Mundo Novo' with the low plant size and compact architecture of the canopy of 'Caturra'. This new cultivar would facilitate adoption of crop treatments and would allow greater density at planting, providing for an increase in yield and reduced cost in crop production. At that time, the reduced size of the plants facilitating the harvest that was completely manual. It is noteworthy that hybridization was carried out in 1949, three years before the release and crop recommendation of 'Mundo Novo' (Carvalho et al. 1952).

Information on genetic control of the compact size of the plants was concluded only after the release of 'Catuai' (Carvalho et al. 1984). The trait is monogenic and the dominant allele Ct is responsible for the low plant size ('Caturra'). Nevertheless, studies related to inheritance of smaller plant size began in the 1940s. In a review published by Krug and Carvalho (1951), the authors called attention not only to the compact plant size but also to good initial yields, especially in regions characterized by a prolonged dry season, as well as to the reduced useful life of the 'Caturra' coffee plants. These initial comments show the considerable observational ability of Dr. Alcides Carvalho.

'Mundo Novo' was obtained by selection made in a plantation of Urupês, the Araraquarense region of the state of São Paulo. According to reports, the crop, with an age of around 12 years, was productive and vigorous, which led the IAC researchers in 1943 to collect cuttings and seeds for multiplication of the plants and tests of their progeny and thus select the best with the aim of recommending the lines. The 'Caturra', had been introduced in 1937, at IAC, originating from Siqueira Campos, ES, although its probable origin is attributed to the Manhumirin, Minas Gerais state.

As 'Caturra Amarelo' (CtCtxcxc) and 'Mundo Novo' $(\operatorname{ctctXcXc)}$ were homozygotes in relation to the genes caturra and xanthocarpa, responsible for plant size and for the color of the fruit, respectively, it was possible, already in the $\mathrm{F}_{1: 2}$ generation, to discard $25 \%$ of the plants still in the nursery that had longer internodes, such as 'Mundo Novo'. In the same generation, but only after fructification, $37.5 \%$ more of the plants were discarded, which, though they were of small size and structure, had orange color fruit $(X c x c)$, due to the incomplete dominance of the $X c$ allele (Krug and Carvalho 1940). In the following generation, progenies segregating in relation to plant size and structure were once more eliminated while still in the plantlet/seedling phase in the nursery, and only the $F_{2: 3}$ coffee plants, homozygous for plant size structure and fruit color, were evaluated in the field. This strategy later allowed release of the current lines of Catuaí Vermelho and Catuaí Amarelo. 
Alcides Carvalho and the selection of Catuaí cultivar: interpreting the past and drawing lessons for the future

Table 2. Identification of experiments, production period, and number of harvests performed, year of selection of the plants and number of harvests considered for generation advancement from $\mathrm{F}_{1}$ to $\mathrm{F}_{3: 4}$ in selection of the Catuaí cultivar of Coffea arabica

\begin{tabular}{lcccc}
\hline Generation & $\mathbf{F}_{1}$ & $\mathbf{F}_{1: 2}$ & $\mathbf{F}_{2: 3}$ & $\mathbf{F}_{3: 4}$ \\
\hline Experiment & EP 8 & EP 30 & EP 50 & Various \\
Planting date & Feb/1952 & Feb/1956 & Jan/1960 & Apr/1965 \\
Location & Campinas & Campinas & Campinas & $1967-$ \\
Production interval & $1954-1969$ & $1958-1971$ & $1962-1974$ & 13 \\
Total harvests & 16 & 14 & 1964 & 3 \\
Selection of the best plants & 1955 & 1959 & 2 & Variable \\
Harvests analyzed for selection & 2 & 2 & \\
\hline
\end{tabular}

*Experiments conducted in Campinas, Mococa, Ribeirão Preto, Monte Alegre do Sul, Ipauçu, and Limeira from 1963 to 1983.

The fact is that from the $3 \mathrm{~F}_{1}$ plants from the cross between 'Caturra Amarelo' and 'Mundo Novo', all the $\mathrm{F}_{1: 2}$ progenies evaluated in the following generation were derived from only one of them, the H2077-2 coffee plant. Selection of this coffee plant occurred according to plant size and structure, fruit yield, vegetative vigor, and lower percentage of seed with defects. This information was well highlighted by Carvalho and Mônaco (1972). In a similar way, of the $447 \mathrm{~F}_{2}$ coffee plants evaluated in 8 experiments set up in 2 locations and of the $1371 \mathrm{~F}_{3}$ coffee plants evaluated in 17 experiments set up in 6 locations, the subsequent $F_{2: 3}$ and $F_{3: 4}$ generations consisted of progenies derived from 9 and 101 coffee plants, respectively (Table 1), selected in an early manner, with data from 2 or 3 harvests.

The insight of Dr. Alcides Carvalho as a breeder is easily perceived upon reading the text that describes selection of the coffee 'Catuaí'. Even after early selection of the best plants in the $F_{1}, F_{1: 2}$, or $F_{2: 3}$ generations, conducted with 2, 2, and 3 harvests, respectively, the experiments were kept in the field, and the yield of each one of the plants individually was noted annually. Although it is not mentioned in the article, he certainly continued to observe the performance of the plants selected in past generations to confirm the correctness of his choices. As an example, experiment EP 30 with $F_{1: 2}$ coffee plants was planted in Campinas, SP, in February 1956, and ripe fruit was harvested from 1958 to 1971. In the following generation, $F_{2: 3}$ progenies were evaluated in the EP 50 experiment set up in Campinas in January 1960, and the plants of the $F_{1: 2}$ generation were selected based only on yield accumulated in 1958 and 1959. The $F_{3: 4}$ generation was planted in various experiments beginning in 1965 with $\mathrm{F}_{2: 3}$ plants selected through mean yield of ripe fruit measured from 1962 to 1964 . As the experiments of the previous generations were kept in the field, on this occasion, data were already available from 7 harvests of EP 30 for confirmation of the correct choice made in 1959 with only 2 harvests (Table 2).

Statistical analyses of experimental data were used in selection of new coffee cultivars from their creation in the 1930s from the coffee breeding program that is conducted until now by the Instituto Agronômico de Campinas (Mendes et al. 1941). However, at that time, current statistical techniques, such as mixed models, were not available in combined analysis of information to subsidize the choice of progenies to be recommended. The strategy is currently advocated in certain occasions to increase the efficiency of selection in autogamous species (Ramalho et al. 2013, Resende et al. 2015, Resende et al. 2016).

In the studies conducted by the team of Dr. Alcides Carvalho, various traits were evaluated; however, the results of our analyses refer only to bean yield from the coffee plants. Adjusted mean values of the plants are shown in Table 3, highlighting $\mathrm{n}^{\circ} 5(\mathrm{H} 2077-2-5)$ derived from the $\mathrm{F}_{1}$ coffee plant of number 2 (H2077-2), the highest mean value of all. This plant received special attention in advancing the generations and, as already mentioned, it was selected in 1959 , three years after planting of the $F_{1: 2}$ generation, and the choice was based on only two harvests.

Table 3. Yield, in kilograms of ripe fruit per plant, in the $F_{2}$ and $F_{3}$ generations adjusted in relation to the control used in the various experiments

\begin{tabular}{|c|c|c|c|}
\hline \multicolumn{2}{|l|}{$F_{2}$ generation } & \multicolumn{2}{|c|}{$F_{3}$ generation } \\
\hline Plant & Yield & Plant & Yield \\
\hline $\mathrm{H} 2077-2-5$ & 7.68 & $\mathrm{H} 2077-2-5$ & 7.68 \\
\hline $\mathrm{H} 2077-2-4$ & 7.37 & $\mathrm{H} 2077-2-4$ & 7.37 \\
\hline H2077-2-56 & 7.29 & H2077-2-56 & 7.29 \\
\hline H2077-2-189 & 6.86 & H2077-2-189 & 6.86 \\
\hline H2077-1-72 & 6.52 & H2077-1-72 & 6.52 \\
\hline . & . & . & . \\
\hline . & . & . & . \\
\hline . & . & . & . \\
\hline H2077-2-18 & -0.72 & H2077-2-18 & -0.72 \\
\hline Mean of Control & 5.62 & Mean of Control & 5.62 \\
\hline
\end{tabular}


The coffee plant $\mathrm{H} 2077-2-5$ gave rise to the best $F_{2 \cdot 3}$ progenies (Table 4 ) and the 16 lines registered as cultivars of Catuaí Vermelho (8) and of Catuaí Amarelo (8). In the decision to advance the $F_{2: 3}$ plants to $F_{3: 4}$ and then distribute the seeds to farmers, performance of the coffee plant $\mathrm{H} 2077-2-5$ in the $F_{1: 2}$ generation was certainly considered.

In the analysis performed with yield of all the progenies of the same $F_{1: 2}$ generation, it is also important to note that in addition to plant 5 already mentioned, numbers $4,56,189$, and 72 stood out (Table 3). Nevertheless, the offspring of these plants with good performance was not evaluated in the $F_{2: 3}$ generation. Probably, though they were higher yielding in the first harvests, these coffee plants had phenotypes for other traits that did not draw the attention of the breeder. In addition, some progenies were planted later, in 1961 or 1962 , when evaluation of the $F_{2: 3}$ progenies had already been performed (the $F_{2: 3}$ plants were planted in 1960, 1961, and 1962).

The number of individuals of each progeny varied greatly, from 30 in the case of progeny H2077-2-37 to 241 in the progeny H2077-2-12. This type of strategy is not highly recommended because, in the genealogical method, selection of the best individuals within the best progenies is used. If the size of the sample is different among the progenies, the information on its merit is impaired. Considering the mean of the progenies, numbers 34, 5, and 12 outperformed. According to reports from Carvalho and Mônaco (1972), plant 12 of the $F_{2}$ generation was heterozygous for the gene caturra (Ctct) and, probably for that reason, the progenies of its descendants were not advanced, even though in the $F_{2: 3}$ generation it had good performance in relation to fruit yield. The most productive $F_{2: 3}$ plant of the H2077-2-5 coffee plant, number 26, occupied position 22 in the ranking of mean values in combined analysis and did not come to be recommended.

Seeds of some $F_{2: 3}$ progenies were distributed to farmers beginning in 1965 , 9 years after planting the $F_{1: 2}$ generation, when data from at least 7 harvests of the plants of this generation were already available, maintained in the field experiments. Decisions for selection of the best plants were made based on statistical analyses of the experimental data of fruit yield, of plant vigor, and of technological characteristics, especially related to the incidence of floaters and seeds of the peaberry and shell type. His discerning observations on each one of the plants were added to these variables as well as a bit of luck, and why not?

The adjusted means per individual of the $F_{2: 3}$ progenies involving all the experiments that had the control in common are shown in Table 3. Notice that in terms of yield, individuals of the $F_{2: 3}$ progenies had wide variation. Among the 5 plants that stood out, 4 were descendants of the $F_{1: 2}$ generation $n^{\circ} 12$ (H2077-2-12), namely number 150, 121, 126, and 108, and 1 was a descendant of H2077-2-34, number 69.

In the $\mathrm{F}_{2: 3}$ generation, in addition to the plant $\mathrm{H} 2077-2-5$, already mentioned, descendants of other plants that were not prominent in the $F_{1: 2}$ generation, that is, those of number $1,6,10,12,30,34,35$, and 37, were included. The adjusted mean values shown in Table 3 involve all the harvests and not just the first. Nevertheless, in our analyses, among these other $8 \mathrm{~F}_{1: 2}$ plants, only no. 12 ( $\left.\mathrm{H} 2077-2-12\right)$ outperformed in combined analysis involving all the generations. The other plants performed near or below the adjusted mean values and, in this case, early selection was not as efficient as in the case of plant 5 (H2077-2-5).

Highlights among the descendants of coffee plant H2077-2-5, after due adjustments, were plants number 105, 26, 144,45 , and 86. Among the 'Catuaí' lines recommended are those of number H2077-2-5-17, -32, -39, -47, -62, -74, -86, and -100 of yellow fruit, and those of number H2077-2-5-24, -44, -72, -81, -15, -51, -99, and-144 of red fruit. It should be noted that 'Catuaí Amarelo', line 62, was most successful, and was probably most grown in many regions, especially the Cerrado Mineiro (tropical savanna region of Minas Gerais). It should be emphasized that this line was selected under a growing condition that is quite different than what occurs this region currently, which is also surprising. 
In the $\mathrm{F}_{3: 4}$ generation, the procedure common to the genealogical procedure continued, i.e., plants were evaluated from each $F_{3}$ coffee plant selected. However, since from the $F_{2: 3}$ generation, seeds were distributed to some farmers, the genealogy from which it was recommended does not mention the $F_{3: 4}$ generation. Thus, the results to be presented will not emphasize the performance of each $\mathrm{F}_{4}$ plant, but rather of its $\mathrm{F}_{3: 4}$ progeny (Table 1 ).

The best $\mathrm{F}_{3: 4}$ progenies were $\mathrm{H} 2077-2-5-5, \mathrm{H} 2077-2-5-24, \mathrm{H} 2077-2-5-71, \mathrm{H} 2077-2-5-46$, and $\mathrm{H} 2077-2-5-74$, with yield around $20 \%$ greater than the control (data not shown). Considering that the control IAC 376-4 is one of the lines of the Mundo Novo cultivar, it was possible to obtain plants of lower height that exceeded the standard yield of the time. Of these $F_{3: 4}$ progenies that stood out, only 7 were recommended among the 16 registered in the Brazilian Ministry of Agriculture (Ministério da Agricultura Pecuária e Abastecimento-MAPA).

Finally, it should be highlighted that of the 16 'Catuai' lines recommended, all were derived from a single $F_{1: 2}$ plant, even though 207 plants in this generation and 1371 plants in the $F_{2: 3}$ generation, coming from $9 F_{1: 2}$ plants, were evaluated. These results reinforce what has already been commented regarding the insight of the breeder in early choice of the plants in the $F_{1}, F_{1: 2^{2}}$ and $F_{2: 3}$ generations, and in the results being quite consistent with what was obtained after 10-14 harvests of $F_{1: 2}$ plants and 6-12 harvests of $F_{2: 3}$ coffee plants. In addition, of the 16 cultivars registered, 15 originate from $F_{2: 3}$ coffee plants of a single experiment, EP 50, set up in Campinas, and only one, IAC 144, comes from an $F_{2: 3}$ coffee plant of the experiment EP 57 planted in Pindorama, SP. This information is little known, even today.

Another surprising fact is that apparently the results of evaluation of the $F_{3: 4}$ generation were not considered in recommendation of the lines to producers. In our analyses we found that the mean of all the progenies derived from the plant H2077-2-5 $\left(\mathrm{F}_{1: 2}\right)$ was $18 \%$ less than 'Mundo Novo IAC 376-4'. The progenies coming from the plants H20772-10 and H2077-2-12 $\left(F_{2}\right)$, which also excelled in $F_{1: 2}$, were $44 \%$ and $32 \%$ lower in relation to the control, respectively, showing that the descendants of plant 5 were also the best in the $F_{3: 4}$ generation.

The selection process of 'Catuaí', began by Alcides Carvalho in 1949, allowed distribution of numerous productive lines with compact size to producers 15 years later. It can be considered that the final phase of the selection program had the participation of producers in evaluating the performance of this new coffee plant, officially released in 1972 in various production regions of Brazil. In 1999, 16 lines were registered as cultivars of Catuaí Vermelho (8) and Catuaí Amarelo (8) in MAPA and currently, 45 years after the release, 'Catuaí' continues as the main Brazilian cultivar of arabica coffee.

Results of 116 cultivar competition trials, containing lineages of 'Catuai', published from 1973 to 2017 in the Summaries of the Brazilian Coffee Research Conference show that Catuaí lines was evaluated in all Brazilian regions, and it has excelled over a long period in a large portion of the experiments. Although, nowadays, the new cultivars are quite interesting.

In our combined analysis with data from field experiments of these progenies in the $F_{1}$ to $F_{3: 4}$ generation (1952 to 1980 ), we sought to adjust the means of progenies in relation to a common control, the cultivar Mundo Novo IAC 376 4. This approach allowed us to analyze 445 coffee plants in 6 experiments in the $F_{1: 2}$ generation derived from the plant H2077-2 and 1154 coffee plants in the $F_{2: 3}$ generation. In spite of the limitations imposed by the impossibility of analyzing the entire data set, the results we obtained showed that 7 of the 16 cultivars registered exhibited mean values greater than 'Mundo Novo IAC 376-4'. However, it should be highlighted that the best lines were selected not only based on fruit yield but also on other important agronomic and technological characteristics, as well as on visual evaluation of the plants carried out with the exceptional biological and agronomic knowledge of the breeder.

Some suggestions in carrying out the coffee breeding programs with the facilities currently available can be indicated. The first is to always use the same common controls, preferentially, more than one. That way, if there is the need for separating the experiments of progeny evaluation, they will be more easily clustered. In this case also, the information of plants as of the $F_{2}$ generation can be used in selection of individuals/progenies in advanced generations. The availability of seeds from the progenies beginning with the $F_{3}$ generation, as was performed by Dr. Alcides, is an excellent strategy. However, with the cultivar protection law, it is unfeasible. The option is to register the greatest number of progenies/ lines and let the market help in definition of the lines that will remain on the market. 


\section{ACKNOWLEDGEMENTS}

Our thanks to Angela de Fátima Barbosa Abreu and Scheila Roberta Guilherme for their collaboration in the analysis carried out. The authors are grateful to the National Council for Scientific and Technological Development (CNPq) for a research scholarship to OGF (CNPq DT 308.634/2016-0) and MAPR.

\section{REFERENCES}

Carvalho A (1965) Genética e melhoramento do cafeeiro. Ciência e Cultura 17: 549-554.

Carvalho A and Mônaco LC (1972) Transferência do fator caturra para o cultivar Mundo Novo de Coffea arabica. Bragantia 31: 379-399.

Carvalho A, Krug CA, Mendes JET, Antunes Filho $\mathrm{H}$, Morais $\mathrm{H}$, Aloisi Sobrinho J, Vieira de Morais M and Ribeiro da Rocha T (1952) Melhoramento do cafeeiro: IV - café Mundo Novo. Bragantia 12: 97-130.

Carvalho A, Medina Filho HP, Fazuoli LC and Costa WM (1984) Genética de coffea XXVI- hereditariedade do porte reduzido do cultivar caturra. Bragantia 43: 443-458.

Krug CA and Carvalho (1951) The genetic of coffee. Advances in Genetics 4: 127-158.

Krug CA and Carvalho A (1940) Genética de Coffea III- Hereditariedade de cor amarela dos frutos. Instituto Agronômico, Campinas, p. 36.
Mendes JET, Brieger FG, Krug CA and Carvalho A (1941) Melhoramento de Coffea arabica L. var. Bourbon. Estudo das produções individuais de 1107 cafeeiros no período 1933 a 1939 e resultados parciais de algumas de suas progênies. Bragantia 1: 3-176.

Ramalho MAP, Carvalho BL and Nunes JAR (2013) Perspectives for the use of quantitative genetics in breeding of autogamous plants. ISRN Genetics 2013: 1-6.

Resende MDV, Ramalho MAP, Carneiro PCS, Carneiro JES, Batista LG and Gois IB (2016) Selection index with parents, populations, progenies, and generations effects in autogamous plant breeding. Crop Science 56: $530-546$

Resende MDV, Ramalho MAP, Guilherme SR and Abreu AFB (2015) Multigeneration index in the within progenies bulk method for breeding of self-pollinated plants. Crop Science 55: 1202-1211.

Steel RGD, Torrie JH and Dickey DA (1997) Principles and procedures of statistics: A biometrical approach. McGraw-Hill,New York, 666p. 